\title{
Exploring the Accounting History Research in Turkey: Publishing Patterns of Academicians
}

\author{
Ali Coskun \\ Associate Professor of Accounting, PhD, Fatih University, Turkey \\ Email: alicoskun@fatih.edu.tr \\ Ali Haydar Gungormus \\ Assistant Professor of Accounting, PhD, Fatih University, Turkey \\ Email: ahgungor@fatih.edu.tr
}

Doi:10.5901/mjss.2015.v6n4p323

\begin{abstract}
The aim of the study is to determine how much interest the accounting academicians have in the history of their field. To analyze this interest we reviewed the academic research of the accounting academicians in Turkey on accounting history. The study explores publishing patterns in Turkish accounting academicians in academic journals and the thesis submitted in Turkish Universities on accounting history. In the study we analyzed and reported the recent development of the accounting history research in Turkey in the period 2000 to 2013. In the study we implemented a content analysis for academic articles. Firstly a comprehensive literature review has been done to find the accounting history articles published by the Turkish academicians in the last decade. We found 74 accounting history articles published in national and international academic journals by the Turkish academicians. The analysis of the articles examined the patterns of authorship, the most published authors, institutional affiliations of authors, author gender, the most published journals, subject areas, and period covered by the articles. In the second part of the study is a content analysis for the master and doctoral thesis on accounting history in Turkish Universities is provided. We searched the theses in the thesis database of The Council of Higher Education of Turkey. We limited the research on accounting history thesis, and we found only 11 theses on accounting history. The analysis of the theses examined the authorship, institutions thesis submitted, advisor of the thesis, subject areas, and period covered by the theses.
\end{abstract}

Keywords: Accounting history, publishing patterns, authorship analysis, content analysis, Turkey.

\section{Introduction}

Since the nearly 15 millions of the 95 millions documents and 180 thousands of the 360 thousands books in Ottoman Achieves are related to accounting (Can \& Esen, 2010), the emergence of the research in Turkish accounting history is clearly seen. In last decade there have been significant improvements in accounting history research in Turkey.

As mentioned by De Serra Faria (2008) with the promotion of the associations in many countries there is an increasing interest in accounting history in recent decades. In Turkey the main motivator of these improvements is the activities supported by two organizations: Turkish Association of Accounting and Finance Association (MUFAD) and The Association of Accounting and Finance History Researchers (MUFITAD). In addition the encouragement and leadership of distinguished accounting history professor Oktay Guvemli, the establisher of these two national associations. $1^{\text {st }}$ and $2^{\text {nd }}$ is significant. Balkans and Middle East Countries Conferences on Accounting and Auditing History (BMAC) were organized in 2007 and 2010 by MUFAD. The 12th World Congress of Accounting Historians (WCAH), the world biggest academic event of accounting history, also hosted by MUFAD in Istanbul in 2008. MUFITAD was established in 2011 and a new journal, the Accounting and Financial History Research Journal was launched as the journal of MUFITAD. These associations organized the participation of the Turkish academicians to the $4^{\text {th }}, 8^{\text {th }}, 9^{\text {th }} 10^{\text {th }}, 11^{\text {th }}, 12^{\text {th }}$ and $13^{\text {th }}$ World Congress of Accounting Historians and the $7^{\text {th }}, 8^{\text {th }}, 9^{\text {th }}, 11^{\text {th }} 16^{\text {th }}$ and $17^{\text {th }}$ World Congress of Accountants (Orten, 2007). The number of the participants from Turkey and the papers presented by them has been increased during the years.

As a result of these progresses the number of books, articles and proceedings of the Turkish academicians on accounting history research increased in the last decade. In recent years Turkish accounting academicians presented papers not only in the BMAC and WACH in Istanbul, but also participated in the International Conferences such as 
Accounting History International Conferences, World Congresses of Accounting Historians, and International Conference before and after Luca Pacioli. They published in national and international journals both in Turkish and English.

The main objective of the study is to evaluate the current situation of the accounting history research in Turkey and to investigate the problems and opportunities of developing the research in the accounting history area. In the study improvements in the academic research of the Turkish academicians on accounting history is analyzed. The study limited with the refereed articles in academic journals and the thesis submitted to the universities in Turkey on accounting history between 2000 and 2013.

\section{Literature Review}

Over the last forty years accounting history has emerged as an academic discipline and there are significant number of researchers, journals and conferences in this field (Richardson, 2008). Important developments in the accounting history area result an increase in the publications in this area (Carnegie et al. 2003; Carmona, 2006, De Serra Faria, 2008; Sánchez-Matamoros \& Hidalgo, 2011).

In recent years there are several researches conducted studies on the publishing patterns of the academicians in accounting history (Carnegie \& Napier, 2002; Anderson, 2002; Carnegie et al., 2003; Williams \& Wines, 2006; Shimizu et al., 2007; De Serra Faria, 2008; Fleischman \& Schuele, 2009; Bisman, 2011; Sánchez-Matamoros \& Hidalgo, 2011; Bisman 2012).

Anderson (2002), Williams \& Wines (2006) and Bisman (2012) analyzed the articles in one of the specialized history journal. Anderson (2002) analyzed the articles published in the Accounting, Business and Financial History using standard content and citation techniques. The analysis included the leading individual and institutional contributors to the journal in three main criteria such as authorship of study, focus of study, and significant influences upon area of study. Williams \& Wines (2006) performed a content analysis of publications in the new series of the journal Accounting History by examining patterns of authorship, the journal's most published authors, institutional and geographical affiliations of authors, author gender and article classifications. Bisman (2012) examined the articles that have appeared in the Accounting History journal using a series of thematic landscapes depicting dominant research trends and trajectories and analyzed the increasing and declining interests in the areas of historical accounting research.

Shimizu et al. (2007) and De Serra Faria (2008) studied the accounting history research in one country. Shimizu et al. (2007) evaluated the accounting history research in Japan in terms of subject classifications, Geographic area of research, time period of the research and trends in Japanese research and prolific authors. De Serra Faria (2008) reported the development of accounting history research in Portugal and analyzed the publishing patterns in the Portuguese accounting journals in the areas such as the number of articles per journal, the gender of authors and the period and subject areas of the articles.

Sánchez-Matamoros \& Hidalgo (2011) examined the publishing patterns of accounting history research in generalist accounting journals. In their study the title of the article, number of authors, the year and name of the publication, the period and setting analyzed, type of paper, institutions affiliation of the authors, and the countries of the authors of the articles were analyzed in the selected journals.

In other researches different aspects of the publication patterns were analyzed. For example, Carnegie et al. (2003) examined the publishing patterns of the women authors in the in the international accounting history literature. They conducted a gender analysis in the areas of location of the authors by gender, patterns of authorship by women, and location of women by country on the basis of English or non-English language dichotomy in three accounting journals: Accounting Historians Journal, Accounting, Business and Financial History Journal and Accounting History. Fleischman \& Schuele (2009) analyzed the co-authorship patterns in accounting history, both quantitatively and qualitatively. Bisman (2011) analyzed the accounting history research publications through a citation analysis in articles published in three specialized accounting history journals. The analysis presented the journal network, influential articles, and the scholarly community of accounting history in these journals.

\section{Research Method}

As mentioned by Bisman (2011) "publication in a scholarly journal is a key ingredient in assessing and establishing the academic merit of a work and that of the author".

The main focus of this study is the refereed articles by the Turkish academicians and the thesis submitted to the universities in Turkey on accounting history. This study does not include the proceedings, working papers, notes, editorials, book reviews, reports and books. A total of 74 individual articles and 11 theses were analyzed in this study (For 
a complete list of articles and the theses surveyed, please contact the corresponding author). The study covers the period between 2000 and 2013.

Articles are analyzed in the four criteria: distribution of articles per publication years, authorship analysis, distribution of articles per journal, and focus of the articles. The Theses are analyzed in the five criteria: submission years, authorship analysis, institutions thesis submitted, advisor of the thesis, subject areas, and period covered by the theses.

\subsection{Analysis of the Articles}

This part of the study is a content analysis of the articles of Turkish academicians on accounting history.

\subsubsection{Distribution of Articles per Publication Years}

Table 1 shows publication periods of the accounting history articles, by aggregating into periods of three years. Table 1 indicates that the number of articles published by Turkish academicians continuously increased over the period 2000 to 2013.

Table 1: Distribution of articles per publication years

\begin{tabular}{cc}
\hline Period & Number of Articles \\
\hline $2000-02$ & 2 \\
$2003-05$ & 9 \\
$2006-08$ & 12 \\
$2009-11$ & 30 \\
$2012-13$ & 21 \\
\hline Total & 74 \\
\hline
\end{tabular}

Approximately 69 percent of the articles are published in last five years. Figure 1 shows that the highest number of articles is published in 2011 and 2012 (15 articles and 13 articles respectively).

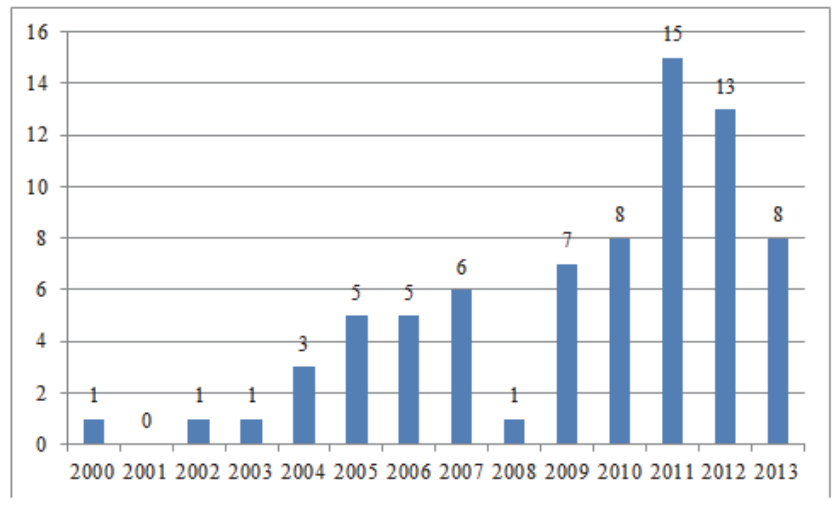

Figure 1. Number of articles published by Turkish academicians on accounting history

\subsubsection{Authorship analysis}

In this section an authorship analysis will be undertaken for the accounting history articles published by the Turkish academicians between 2000 and 2013. The analysis is performed under the following headings:

- $\quad$ Patterns of authorship;

- The most published individual authors;

- Institutional affiliation of authors;

- Author gender analysis; 


\subsubsection{Patterns of Authorship}

Williams \& Wines (2006) indicated that there is a trend in the international research publication in accounting history area. They explained the reasons of the increasing collaborations among the academicians as greater demands on academics mean it is more difficult for individuals to research alone. They also indicated that, there is greater encouragement by universities for collaboration, particularly between senior and junior members of staff. In Turkey despite the majority of the articles are still single authored, there is a trend to collaborations among the academicians in recent years. As the results of this study shown in Table 2 the 62.2 percent of the articles were single authored, 23 per cent of the articles had two authors, and 14.8 percent of the articles had three or four authors. Before 2009 the great majority $(79.2 \%)$ of the articles were single authored while only 4 out of 24 had two authors. Between 2009 and 2013 there is a change in publication pattern of the Turkish accounting academicians and the collaborations among the academicians has been improved.

Table 2. Pattern of Authorship

\begin{tabular}{cccccc}
\hline Year & Single Author & Two Authors & Three Authors & Four Authors & Number of Articles \\
\hline 2000 & 1 & - & - & - & 1 \\
2001 & - & - & - & - & 0 \\
2002 & 1 & - & - & - & 1 \\
2003 & 1 & - & - & - & 1 \\
2004 & 3 & - & - & - & 3 \\
2005 & 5 & - & - & - & 5 \\
2006 & 2 & 2 & 1 & - & 5 \\
2007 & 4 & 2 & - & - & 6 \\
2008 & 1 & - & - & - & 1 \\
2009 & 2 & 2 & 2 & 1 & 7 \\
2010 & 5 & 2 & 1 & - & 8 \\
2011 & 8 & 5 & 2 & - & 15 \\
2012 & 10 & 1 & 2 & & 13 \\
2013 & 3 & 3 & 2 & & 8 \\
Total & 46 & 17 & 10 & 1 & 74 \\
\hline Percentage & $62,2 \%$ & $23,0 \%$ & $13,5 \%$ & $1,4 \%$ & $100,0 \%$ \\
\hline
\end{tabular}

Between 2009 and 2013 nearly half of the articles are co-authored, 23 articles had two or more authors while 27 articles were single authored (Figure 2).

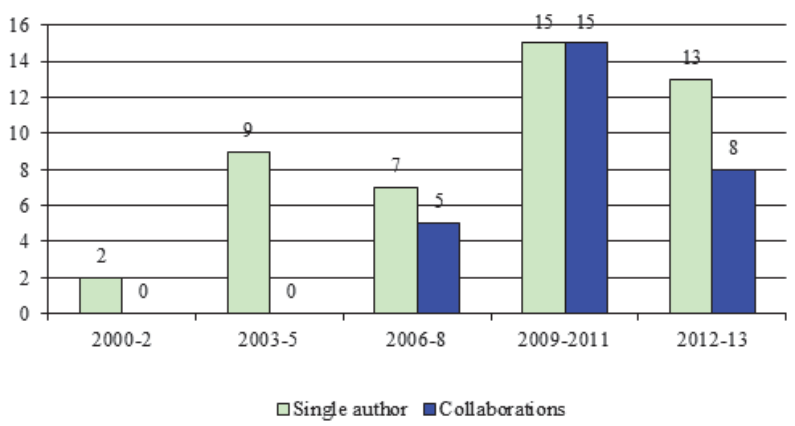

Figure 2. Pattern of the publication

Fleischman \& Schuele (2009) suggests accounting history researchers to improve the collaboration with the other disciplines such sociologists and psychologists in order to expand the understanding of the parameters of the accounting's history. In this research we found out that all co-operations are within the same areas, co-authors are all in accounting departments. There are a few articles written by one author from accounting department one from history. 


\subsubsection{The Most Published Authors}

Because of some authors have multiple publications; there were 114 authors of the 74 research articles published between 2000 and 2013. There were 62 individual authors 19 of which have had multiple articles. A summary of the authors with multiple articles is presented in Table 3. The most published author was Kayhan Orbay, the author fifteen articles. Oktay Guvemli followed him with eight articles. After them Batuhan Guvemli and Mehmet Erkan come, authors of five articles each. In terms of weighting number of multiple articles Kayhan Orbay and Oktay Guvemli have the highest number of articles. Batuhan Guvemli follows them with 3.30 articles. After them, İsmail Kucuk, Temel Ozturk, İsmail Otar and İhsan Fazlioglu had the highest number of weighted articles with two weighted articles each, represented by two single authored articles.

Table 3. The Most Published Authors

\begin{tabular}{llcc}
\hline Author Name & University & Total Number & Weighted Total \\
\hline Orbay, Kayhan & Historian /Middle East Technical University (2007) & 15.0 \\
Guvemli, Oktay & Marmara University & 8 & 6.5 \\
Guvemli, Batuhan & Trakya University & 5 & 3.3 \\
Kucuk, İsmail & Accountant & 3 & 2.0 \\
Otar, İsmail & Historian & 2 & 2.0 \\
Fazlioglu, İhsan & İstanbul University & 2 & 2.0 \\
Ozturk, Temel & Karadeniz Teknik University & 2 & 2.0 \\
Erkan, Mehmet & Afyon Kocatepe University/ İstanbul University (2012) & 5 & 1.9 \\
Toraman, Cengiz & Zonguldak Karaelmas University & 3 & 1.7 \\
Yukcu, Suleyman & Dokuz Eylul University & 3 & 1.5 \\
Sipahi, Baris & Marmara Universitesi & 1.5 \\
Gucenme, Umit & Uludag University & 3 & 1.5 \\
Elitas, Cemal & Afyon Kocatepe University & 2 & 1.4 \\
Aydemir, Oguzhan & Afyon Kocatepe University & 4 & 1.4 \\
Can, Ahmet Vecdi & Sakarya University & 4 & 1.3 \\
Coskun, Fatih Ertas & Gaziosmanpasa University & 2 & 1.0 \\
Atagan, Gulsah & Dokuz Eylul University & 2 & 1.0 \\
Bayramoglu, Fatih & Zonguldak Karaelmas University & 2 & 0.7 \\
Elitas, Bilge Leyli & Afyon Kocatepe University & 2 & 0.6 \\
Others & & 2 & 25.7 \\
\hline Total & & 43 & 74 \\
\hline
\end{tabular}

\subsubsection{Institutional Affiliation of Authors}

In this section, institutional affiliations of the 62 individual authors are analyzed. 55 of the 62 individual authors are from 29 different universities, and remaining 7 authors are from other institutions. The weighted number of the articles of the authors who are from a university is 61.5 whereas the individuals' number is 12.5 . The highest weighted number of articles is from Middle East Technical University while the highest number of articles is from Afyon Kocatepe University.

Table 4. Institutional Affiliation of Authors

\begin{tabular}{lcccccc}
\hline University & Single Author & Two Authors & Three Authors & Four Authors & Total & Weighted Total \\
\hline Middle East Technical University & 11 & & & & 11 & 11.0 \\
Marmara University & 5 & 6 & 0 & 0 & 11 & 8.0 \\
Afyon Kocatepe University & 0 & 4 & 6 & 4 & 14 & 5.0 \\
Dokuz Eylul University & 1 & 6 & 0 & 0 & 7 & 4.0 \\
Trakya University & 2 & 3 & 1 & 0 & 6 & 3.8 \\
İstanbul Universitesi & 3 & 0 & 1 & 0 & 4 & 3.3 \\
Gazi University & 1 & 0 & 5 & 0 & 6 & 2.7 \\
Uludag University & 1 & 3 & 0 & 0 & 4 & 2.5 \\
Zonguldak Karaelmas University & 1 & 0 & 4 & 0 & 5 & 2.3 \\
Akdeniz University & 1 & 0 & 3 & 0 & 4 & 2.0 \\
Other & 21 & 9 & 10 & 0 & 40 & 28.8 \\
\hline Total & 30 & 22 & 18 & 4 & 114 & 74 \\
\hline
\end{tabular}




\subsubsection{Author Gender Analysis}

A gender analysis of the authors contributing to accounting history literature shows that overwhelming majority of the authors was male. There were 46 individual male authors and 16 female. Table 5 dissects author gender between single, dual, triple and four authored articles. The breakdown of the authors indicates that 82.5 per cent of the authors (94 authors) were male in this period and 17.5 per cent were female (20 authors). In terms of weighted number of multiple articles 64.25 of the 74 articles (86.8 \%) authored by male. The data indicates that the majority of female participation was at double and triple authored articles ( 85 percent).

Table 5. Authorship by gender (number of author)

\begin{tabular}{ccccccc}
\hline Gender & Single Author & Two Authors & Three Authors & Four Authors & Total Number & Weighted Total \\
\hline Male & 43 & 27 & 21 & 3 & 94 & 64.25 \\
Female & 3 & 7 & 9 & 1 & 20 & 9.75 \\
\hline Total & 46 & 34 & 30 & 4 & 114 & 74.0 \\
\hline
\end{tabular}

On the other hand the first author of was male in 89.1 percent of the articles as shown in Table 6 . The results indicate that men have been dominating the accounting history research in Turkey as it's seen both in weighted total number of publications and the author orders in the articles.

Table 6. Authorship by gender (author order)

\begin{tabular}{ccccccc}
\hline Gender & First author & Second author & Third author & Forth author & Total Number & Percentage \\
\hline Male & 68 & 20 & 6 & - & 94 & $82.5 \%$ \\
Female & 6 & 8 & 5 & 1 & 20 & $17.5 \%$ \\
\hline Total & 74 & 28 & 11 & 1 & 114 & $100.0 \%$ \\
\hline
\end{tabular}

\subsubsection{Distribution of Articles per Journal}

The classification of the articles according to the journals published showed that the articles are published in 44 different national and international journals. Thirty five percent of the articles were published in two journals: 18 articles in Muhasebe ve Finans Tarihi Arastirmalari Dergisi (Journal of Accounting and Finance History Researches) and 8 articles in Muhasebe ve Finansman Dergisi (Journal of Accounting and Finance). These two journals are established by distinguished accounting history professor Oktay Guvemli who encourages Turkish accounting academicians in studying in accounting history. With the other journals the number of accounting history articles published in the journals of the accounting associations reaches to 33. The number of the accounting history articles published in university journals is 14 , and the number in other academic social science journals is 12. Additionally, Turkish academicians also published 15 accounting history articles in international journals such as Accounting History, Accounting Historians Journal, De Computis: Spanish Journal of Accounting History, International Journal of Business \& Social Science, African Journal of Business Management, Rivista degli Studi Orientali, Revue D'Etudes Turques, Acta Orientalia: Academiae Scientiarum Hung, Wiener Zeitschrift fur die Kunde des Morgenlandes, Zeitschrift fur die Welt der Turken, International Journal of Food and Agricultural Economics, Journal of the Economic and Social History of the Orient, Pecvnia and International Journal of Social Science.

Table 7. Distribution of Articles per Journal

\begin{tabular}{|c|c|c|c|}
\hline Type of Journal & Name of the Journal & Number of Articles & Total number \\
\hline $\begin{array}{l}\text { Journals of } \\
\text { Accounting }\end{array}$ & $\begin{array}{l}\text { Muhasebe ve Finans Tarihi Arastirmalari Dergisi (Journal of Accounting and Finance } \\
\text { History Researches) }\end{array}$ & 18 & \multirow{6}{*}{33} \\
\hline \multirow[t]{5}{*}{ Associations } & Muhasebe ve Finansman Dergisi (Journal of Accounting and Finance) & 8 & \\
\hline & Mali Çozum Dergisi (Journal of Financial Solution) & 3 & \\
\hline & Muhasebe ve Denetime Bakis (Accounting and Auditing View) & 2 & \\
\hline & Mali Kilavuz (Financial Guide) & 1 & \\
\hline & Muhasebe Bilim Dunyasi Dergisi (World of Accounting Science Journal) & 1 & \\
\hline University & Akademik Bakis & 1 & \multirow{2}{*}{14} \\
\hline Journals & Bilig: Turk Dunyasi Sosyal Bilimler Dergisi & 1 & \\
\hline
\end{tabular}




\begin{tabular}{|c|c|c|c|}
\hline & Bogaziçi Journal: Review of Social, Economic and Administrative Studies & 1 & \\
\hline & Dumlupinar Universitesi Sosyal Bilimler Dergisi & 1 & \\
\hline & İstanbul Universitesi Edebiyat Fakultesi Tarih Dergisi & 1 & \\
\hline & Kilis Universitesi İ̈BF Dergisi & 1 & \\
\hline & Hacettepe Universitesi Turkiyat Arastirmalari Dergisi & 1 & \\
\hline & Ege Akademik Bakis & 1 & \\
\hline & Ankara Universitesi Tarih Arastirmalari Dergisi & 1 & \\
\hline & Ankara Universitesi Osmanli Tarihi Arastirma ve Uygulama Merkezi (OTAM) Dergisi & 1 & \\
\hline & Yalova Sosyal Bilimler Dergisi & 1 & \\
\hline & $\begin{array}{l}\text { Ankara Universitesi Guneydogu Avrupa Çalismalari Uygulama ve Arastirma Merkezi } \\
\text { Dergisi }\end{array}$ & 1 & \\
\hline & Uludag Universitesi Fen Edebiyat Fakultesi Sosyal Bilimler Dergisi & 1 & \\
\hline & İstanbul Universitesi İktisat Fakultesi Mecmuasi & 1 & \\
\hline \multirow{10}{*}{$\begin{array}{l}\text { Academic Social } \\
\text { Science Journals }\end{array}$} & Vakiflar Dergisi & 3 & \multirow{10}{*}{12} \\
\hline & İktisat İsletme ve Finans Dergisi & 1 & \\
\hline & Kamu Hesaplarina Uzman Bakis Dergisi & 1 & \\
\hline & Osmanli Arastirmalari & 1 & \\
\hline & Tarih Arastirmalari Dergisi & 1 & \\
\hline & Belleten - Turk Tarih Kurumu & 1 & \\
\hline & Turk Dunyasi İncelemeleri Dergisi & 1 & \\
\hline & Turkiye Arastirmalari Literatur Dergisi & 1 & \\
\hline & Sayistay Dergisi & 1 & \\
\hline & Kutadgubilig: Felsefe Bilim Arastirmalari Dergisi & 1 & \\
\hline \multirow{15}{*}{$\begin{array}{l}\text { International } \\
\text { Journals }\end{array}$} & De Computis & 2 & \multirow{14}{*}{15} \\
\hline & Accounting History & 1 & \\
\hline & Accounting Historians Journal & 1 & \\
\hline & Acta Orientalia: Academiae Scientiarum Hung. & 1 & \\
\hline & African Journal of Business Management & 1 & \\
\hline & International Journal of Business \& Social Science & 1 & \\
\hline & International Journal of Food and Agricultural Economics & 1 & \\
\hline & International Journal of Social Science & 1 & \\
\hline & Journal of the Economic and Social History of the Orient & 1 & \\
\hline & Pecvnia & 1 & \\
\hline & Revue D'Etudes Turques & 1 & \\
\hline & Rivista degli Studi Orientali & 1 & \\
\hline & Wiener Zeitschrift fur die Kunde des Morgenlandes & 1 & \\
\hline & Zeitschrift fur die Welt der Turken & 1 & \\
\hline & Total & 74 & \\
\hline
\end{tabular}

\subsubsection{Main Focus and the Coverage of the Articles}

In this section focus of the articles are analyzed in terms of study subject area and the time period of the article.

\subsubsection{Subject of the Study}

The analysis reveals that the three areas of "accounting of waqfs", "history of double-entry accounting" and "governmental accounting" account for almost 62.2 percent of the articles. The subject categories of the articles are summarized in Table 8.

Table 8. Subject of the study

\begin{tabular}{lcc}
\hline Subject & Number of Articles & Percentage \\
\hline Accounting of Waqfs (foundations) & 22 & $29,7 \%$ \\
History of bookkeeping & 13 & $17,6 \%$ \\
Governmental accounting & 11 & $14,9 \%$ \\
Development of accounting & 6 & $8,1 \%$ \\
History of accounting education & 6 & $8,1 \%$ \\
Cost accounting & 5 & $6,8 \%$ \\
Accounting history research and literature & 3 & $4,1 \%$ \\
Auditing & 2 & $2,7 \%$ \\
Other (real estate acc., agriculture acc., acc. occupation, etc.) & 6 & $8,1 \%$ \\
\hline Total & 74 & $100,0 \%$ \\
\hline
\end{tabular}




\subsubsection{Time Period Covered in the Study}

The time period examined in the accounting history articles of Turkish academicians in Table 9 and Table 10 present. Most of the articles address the Ottoman period while articles about the Turkish Republic era follows it.

Table 9: Time Period Covered in the Study

\begin{tabular}{cc}
\hline Period & Number of Articles \\
\hline Ottoman Period & 48 \\
Turkish Republic Period & 20 \\
Ilkhanate and Abbasiad Period & 6 \\
Other & 7 \\
\hline
\end{tabular}

The analysis also shows that the most emphasized to the period from the seventeenth century to twentieth century. The results show that, Turkish academicians mostly studying the near history, but far less research are conducted before fifteenth century.

Table 10: Time Period of Study (by century)

\begin{tabular}{cc}
\hline Period & Number of Articles \\
\hline $12^{\text {th }}-14^{\text {th }}$ century & 5 \\
$15^{\text {th }}-16^{\text {th }}$ century & 11 \\
$17^{\text {th }}-18^{\text {th }}$ century & 26 \\
$19^{\text {th }}$ century & 18 \\
$2^{\text {th }}$ century & 22 \\
N/A & 8 \\
\hline
\end{tabular}

\subsection{Analysis of the Theses}

This part of the study is a content analysis for the master and doctoral thesis on accounting history in Turkish Universities is provided. We searched the theses in the thesis database of The Council of Higher Education of Turkey (YOK). We limited the research on accounting history theses, after searching with several different keywords we found only 11 theses on accounting history. The analysis of the theses examined the patterns of authorship, institutions thesis submitted, advisor of the thesis, subject areas, and period covered by the theses.

Even there are very few number of these prepared in accounting history there is a growing interest to the field. Thus 10 of the theses were submitted after 2007 while there is only one thesis before that year. Another important point is that the most of the theses is PhD thesis (Table 11).

Table 11: Distribution of theses per years submitted

\begin{tabular}{cccc}
\hline Years & Master Thesis & PhD Thesis & Total Number of Thesis \\
\hline $2000-2006$ & - & 1 & 1 \\
$2007-2010$ & 3 & 3 & 6 \\
$2011-2013$ & 4 & & 4 \\
Total & 7 & 4 & 11 \\
\hline
\end{tabular}

The theses are submitted nine different universities as shown in Table 12. This indicates that there isn't any department focusing the accounting history research in Turkish universities. On the other hand The universities which have the highest number of articles published such as Middle East Technical University, Afyon Kocatepe University, Uludag University, Zonguldak Karaelmas University, Akdeniz University and Dokuz Eylul University do not have any submitted thesis. 
Table 12: Universities theses submitted

\begin{tabular}{lc}
\hline University & Number \\
\hline İstanbul University & 2 \\
Marmara University & 2 \\
Ankara University & 1 \\
Balikesir University & 1 \\
Bogaziçi University & 1 \\
Gazi Osman Pasa University & 1 \\
Sakarya University & 1 \\
Trakya University & 1 \\
Ufuk University & 1 \\
\hline Total & 11 \\
\hline
\end{tabular}

Table 13 shows which departments the theses are submitted. Only four of the accounting history theses were supervised by an accounting professor. Three of the theses were submitted either to a history or an Islamic history department. The others were submitted to finance, economics history, economics, and literature departments.

Table 13: Departments theses submitted

\begin{tabular}{lc}
\hline Department & Number \\
\hline Accounting & 4 \\
Finance & 1 \\
History & 2 \\
Islamic History & 1 \\
Economics History & 1 \\
Economics & 1 \\
Literature & 1 \\
\hline Total & 11 \\
\hline
\end{tabular}

The other interesting point is that only two of the thesis advisor published an accounting history article. As presented in Table 14 the mostly Ottoman period was studied in the accounting history theses. Remaining theses address the Turkish Republic era.

Table 14: Time Period covered by the Thesis

\begin{tabular}{cc}
\hline Period & Number \\
\hline Ottoman & 7 \\
Turkish Republic & 3 \\
Other & 1 \\
\hline Total & 11 \\
\hline
\end{tabular}

\section{Conclusion}

In this study we analyzed the accounting history research of the Turkish academicians in the period 2000 to 2014. For that purpose, a comprehensive literature review completed through databases and libraries to find the refereed accounting history articles published by the Turkish academicians in this period. To find the accounting history theses database of The Council of Higher Education of Turkey (YOK) has been searched using several keywords. A total of 74 individual articles and 11 theses were analyzed.

The results of the study show that there is an increasing interest to the accounting history research among the Turkish accounting academicians in recent years. In last four years the number of accounting history articles reached the highest level of last twelve years. On the other hand the number of the thesis on accounting history is very few even the number has been increased in last four years.

There is an increased number of collaborations among the Turkish accounting academicians after 2009. But the all of the co-authorships are within the same areas, there isn't any articles written by one author from accounting department one from other department. The multidisciplinary studies may provide more understanding of the parameters of the 
history of accounting.

An analysis of the most published authors revealed that some of the authors such as Kayhan Orbay, Oktay Guvemli, Batuhan Guvemli and Mehmet Erkan has been came forward. In gender analysis of the authors contributing to accounting history literature in Turkey, we found that there is male domination, and the majority of the authors both in weighted total number of publications and the author orders in the articles were male.

The articles are published in an enormous variety of journal. Whereas Turkish accounting academicians published 74 accounting history articles in 43 different national and international journals; thirty five percent of these articles were published in top two journals: Muhasebe ve Finans Tarihi Arastirmalari Dergisi (Journal of Accounting and Finance History Researches) and Muhasebe ve Finansman Dergisi (Journal of Accounting and Finance.

The majority of the articles in studied the three main areas of "history of double-entry accounting", "accounting of wagfs" and "history of accounting education". The results show that most of the articles address the Ottoman period while thirty three per cent of the articles are about the Turkish Republic era and only ten percent of the articles about the Ilkhanate and Abbasiad Period. The analysis also shows that the most emphasized to the period from the seventeenth century to twentieth century. The analysis stated that articles in accounting history by Turkish academicians mostly focusing the studying the near history, especially after seventieth century.

Most of the accounting history theses are submitted to the other departments rather than accounting departments. The results of the study indicated that Turkish accounting academicians are interested in publishing articles on accounting history rather than supervising the thesis in this area. There could be several reasons behind this; since inquiries on these reasons are not the subject of this study, further studies can be implemented on this subject.

The results show that even though there is an encouragement of the accounting history associations Turkish accounting academicians still do not have much interest on the history of accounting. The reasons may be considered as the lack of accounting history classes in universities, change in the Turkish alphabet from Arabic letters to Latin letters in the beginning of the $20^{\text {th }}$ century, discouragements on studying Ottoman documents in the early years of the Republic, lack of separate accounting history departments or in the faculties, being the current topics in accounting more popular than accounting history, etc. To investigate and the find out the real reasons of not being motivated in accounting history could be a subject of a further research.

\section{References}

Anderson, M. (2002). An analysis of the first ten volumes of research in Accounting, Business and Financial History, Accounting, Business \& Financial History 12 (1), 1-24.

Bisman, J.E. (2011). Cite and seek: Exploring accounting history through citation analysis of the specialist accounting history journals, 1996 to 2008, Accounting History 16 (2), 161-183.

Bisman, J. E. (2012). Surveying the landscape: The first 15 years of Accounting History as an international journal. Accounting History 17 (1), 5-34

Can, A. V., \& ESEN, S. (2010). "Osmanli Muhasebe Sistemi ve 1530 Yilina lliskin Yapilan Kayitlarin Isiginda Bir Osmanli Livası: Prizren", 2.Uluslararasi Balkanlarda Sosyal Bilimler Kongresi,,Prizren - Kosova. [Online] Available: http://www.mizanturk.com.tr/ Akademi/ Akademi_11420132224616.pdf (April 15, 2014)

Carmona, S., Ezzamel, M. \& Gutiérrez, F. (2004). Accounting History Research: Traditional and New Accounting History Perspectives. De Computis: Spanish Journal of Accounting History (1), 24-53

Carnegie, G. D., \& Napier, C. J. (2002). Exploring comparative international accounting history. Accounting, Auditing \& Accountability Journal 15 (5), 689-718.

Carnegie, G. D., Mcwatters, C. S., \& POTTER, B. N. (2003). The development of the specialist accounting history literature in the English language: An analysis by gender. Accounting, Auditing \& Accountability Journal, 6 (2), 186 - 207

De Serra Faria, A. R. S. (2008). An analysis of accounting history research in Portugal: 1990-2004. Accounting History 13 (3), 353-382.

Fleischman R.K., Schuele, K. (2009). Co-authorship in accounting history: advantages and pitfalls. Accounting, Business \& Financial History 19 (3), 287-303

Orten, R. (2007). Turkey in National and International Accounting Congresses and Symposia. Journal of Financial Analyze (76), 94-115.

Richardson, A. J. (2008). Strategies in the development of accounting history as an academic discipline. Accounting History 13 (3), 247280.

Sánchez-Matamoros, J. B., \& HIDALGO, F.G. (2011). Publishing patterns of accounting history research in generalist journals: Lessons from the past. Accounting History 16 (3), 331-342

Shimizu, Y., Nakano, T., \& Hashimoto, T. (2007). The evolution of accounting history research in Japan: analysis of the research database of Kaikei, 1917-2004. The fifth Accounting History International Conference Proceedings. Canada [Online] Available: http://www.edwards.usask.ca/special/5ahic/papers/5AHIC-80\%20Final\%20paper.pdf (June 15, 2014)

Williams, B., \& Wines, G. (2006). The first 10 years of Accounting History as an international refereed journal: 1996-2005. Accounting History 11 (4), 419-445. 